\title{
TRANSPOSIÇÃO DE INSTITUTOS DO DIREITO PENAL PARA O DIREITO ADMINISTRATIVO SANCIONADOR
}

\section{TRANSPOSITION OF CRIMINAL LAW INSTITUTES TO THE SANCTIONING ADMINISTRATIVE LAW}

\author{
Valter Shuenquener de Araujo ${ }^{1}$ \\ Thaís Ramos Estrella Branco ${ }^{2}$ \\ Vítor do Nascimento Costa ${ }^{3}$
}

\section{RESUMO}

Este artigo destina-se a analisar como alguns dos institutos do Direito Penal podem ser transplantados para o Direito Administrativo Sancionador. O trabalho de pesquisa considerou a metodologia qualitativa, tendo um objetivo descritivo e explicativo. Em relação ao procedimento metodológico adotado, ele é bibliográfico e foca no estudo de como específicos institutos da dogmática do Direito Penal podem ser empregados por outros ramos do Direito. A pesquisa teórica da transposição ficou adstrita aos princípios da legalidade, proporcionalidade, culpabilidade e ao instituto do crime continuado. Ao final, o resultado é favorável à transposição dos institutos investigados para o Direito Administrativo Sancionador desde que observadas algumas adequações expostas ao longo do texto.

Palavras-chave: Direito Administrativo Sancionador, Direito Penal, Transposição de institutos, Princípio da legalidade, Crime continuado.

\begin{abstract}
This article aims to analyze how some of the Criminal Law institutes can be transplanted to the Sanctioning Administrative Law. The research work considered a qualitative methodology, having a descriptive and explanatory objective. Concerning the methodological procedure adopted, it is bibliographical and focuses on how certain Criminal Law institutes can be used by other Law branches. The theoretical research on the transposition limited the analysis to the principles of legality, proportionality, guilt and to the institute of continuous offence. In the end, the result indicates the possibility of the investigated institutes transposition to the Sanctioning Administrative Law, provided that some adjustments presented along the text are observed.
\end{abstract}

\footnotetext{
${ }^{1}$ Professor Adjunto de Direito Administrativo da Graduação e Pós-Graduação e Faculdade de Direito da UERJ Departamento de Direito do Estado, Mestre e Doutor em Direito Público pela UERJ, KZS pela Ruprecht-Karls Universität de Heidelberg. Afiliação: Universidade do Estado do Rio de Janeiro - UERJ, Rio de Janeiro. ORCID: https://orcid.org/0000-0003-1584-5340. Lattes: http://lattes.cnpq.br/8284713431239760. E-mail: vsaraujo19@gmail.com

2 Graduanda e integrante do grupo de pesquisa institucional da Faculdade de Direito da UERJ. Afiliação: Universidade do Estado do Rio de Janeiro - UERJ, Rio de Janeiro Lattes: http://lattes.cnpq.br/1364782789416167. E-mail: thaisestrella_@hotmail.com

${ }^{3}$ Graduando e integrante do grupo de pesquisa institucional da Faculdade de Direito da UERJ. Afiliação: Universidade do Estado do Rio de Janeiro - UERJ, Rio de Janeiro. Lattes: http://lattes.cnpq.br/9241891195903805. E-mail: vitor97costa@ hotmail.com
} 
Keywords: Sanctioning Administrative Law, Criminal Law, Transposition of institutes, Principle of legality, Continuous offence.

\section{INTRODUÇÃO}

O Direito Penal pode ser definido como "o conjunto de normas jurídicas mediante as quais o Estado proíbe determinadas ações ou omissões, sob ameaça de pena" (FRAGOSO, 2003, p. 4). A legislação penal mais antiga que se tem conhecimento é o código do rei Hammurabi, da Babilônia, datado do século XXIII a.C. (entre 2285 e 2242 a.C.) (ZAFFARONI; PIERANGELI, 2004, p. 177). São, portanto, mais de 4.000 anos de desenvolvimento, o que permitiu o surgimento e amadurecimento de diversos princípios e institutos através dos tempos. O mesmo não se presencia no Direito Administrativo Sancionador, disciplina jurídica que se encontra em um estágio de maturidade menos avançado.

O Direito Administrativo pode ser definido como o "conjunto de normas e princípios que, visando sempre ao interesse público, regem as relações jurídicas entre pessoas e órgãos do Estado e entre este e as coletividades a que devem servir." (CARVALHO FILHO, 2017. p. 9). Trata-se de ramo do Direito focado na Administração Pública e nas suas relações com os cidadãos e que somente começa a se desenvolver a partir da Revolução Francesa de 1789, ocasião em que há uma maior limitação dos poderes estatais por meio da constitucionalização do direito (ARAGÃO, 2013, p. 2). Não se deve ignorar, contudo, as raízes autoritárias do Direito Administrativo, de matriz francesa. Em lugar de se preocupar primordialmente com a limitação do poder estatal em benefício do cidadão, o Direito Administrativo se prestou, inicialmente, a consagrar o princípio da autoridade no âmbito do Conselho de Estado francês e a fazer valer a vontade estatal (BINENBOJM, 2008, p. 01).

Ao longo da história mais recente, especialmente após a Segunda Guerra Mundial, houve uma profunda trajetória de influxos entre as sanções administrativas e penais, assim sintetizada por Ana Carolina Carlos de Oliveira:

Este breve histórico permite-nos observar um movimento pendular entre a criminalização de condutas pelo Direito Penal e pelo Direito administrativo sancionador, dependendo das opções políticas de determinada época, da conformação do Estado, mais ou menos intervencionista e também de motivos menos "nobres" para o Direito Penal, como sua instrumentalização, em termos de crise, para garantir o cumprimento de normas protetoras da ordem econômica. (OLIVEIRA, 2012, p. 91). 
Ora uma conduta é sancionada apenas pelo Direito Administrativo, ora pelo Direito Penal, e, não raras vezes, pelos dois ramos. A criminalização do Direito Administrativo e a administrativização do Direito Penal têm ocorrido de forma extremamente dinâmica e, em grande parte das vezes, sem que as escolhas tenham muita racionalidade. Percebe-se não um movimento único, mas uma oscilação constante entre a opção política pela previsão de um crime ou de uma infração administrativa.

O ilícito penal encontra fundamento distinto do administrativo, especialmente em virtude do princípio da intervenção mínima inerente ao Direito Penal. Conforme Claus Roxin, o Direito Penal deve ser a última das medidas possíveis, quando todas as demais falharem: ação civil, regulamentos de polícia, sanções não penais etc. (ROXIN, 1997, p. 65). O Direito Penal, à luz do princípio da fragmentariedade, não protege todos os bens jurídicos, mas apenas aqueles cujas violações possam gerar danos de maior gravidade (JESUS, 2014. p. 52).

O ilícito administrativo, por outro lado, não possui este caráter fragmentário. A atuação da Administração Pública é complexa e se volta à consecução dos mais diversos interesses. Segundo Rafael Munhoz de Mello, a sanção administrativa pode ser compreendida como " $a$ medida aflitiva imposta pela Administração Pública em função da prática de um comportamento ilícito" (MELLO, 2005). Na perspectiva de Marcelo Prates:

Sanção administrativa é a medida punitiva prevista em ato administrativo, que pode ser aplicada diretamente pela Administração no âmbito das suas relações jurídicas gerais, a quem, sem justificação, deixe de cumprir um dever administrativo certo e determinado normativamente imposto (PRATES, 2003, p. $54)$.

Sobre a função da sanção administrativa, Alice Voronoff sustenta que:

Como instrumento que opera de modo primariamente prospectivo, com vista a assegurar e promover a conformação da conduta dos particulares em prol da satisfação de interesses e necessidades sociais, a sanção administrativa é uma ferramenta sui generis. (...) só se justifica se tiver aptidão para produzir os resultados dela esperados, o que pressupõe um conjunto específico de incentivos necessários para direcionar a conduta dos particulares numa ou noutra direção (VORONOFF, 2018, p. 104).

A sanção administrativa disciplinar, por exemplo, "tem natureza eminentemente pedagógica, de modo que o desvio de conduta na prestação do serviço público seja corrigido" (BOCKIE, 2016, p. 353). O foco maior está na restauração do serviço público, e não do servidor. 


\section{PRINCÍPIOS PENAIS DE ESTATURA CONSTITUCIONAL}

Alguns princípios advindos da dogmática penal são dotados de tamanha relevância que foram elevados ao patamar constitucional. Eles estão situados no art. $5^{\circ}$ da Constituição da República na condição de direitos fundamentais. São eles: o princípio da legalidade estrita e da anterioridade penal (art. $5^{\circ}, \mathrm{XXXIX}, \mathrm{CRFB}$ ), a retroatividade da lei penal mais benéfica ao réu (art. $5^{\circ}, \mathrm{XL}, \mathrm{CRFB}$ ), a previsão do caráter inafiançável dos crimes de racismo, tortura, tráfico ilícito de entorpecentes, terrorismo, crimes hediondos e a ação de grupos armados, civis ou militares (art. 5 $5^{\circ}$ XLII, XLIII e XLIV, CRFB), a intranscendência da pena (art. 5, XLV, CRFB), a individualização da pena (art. $5^{\circ}, \mathrm{XLVI}, \mathrm{CRFB}$ ) e a vedação às penas de morte, caráter perpétuo, trabalhos forçados e banimento (art. $5^{\circ}$, XLVII, CRFB). Outros princípios dizem respeito mais diretamente ao processo penal, tais como o devido processo legal (art. $5^{\circ}$, LIV, CRFB), o direito ao contraditório e à ampla defesa dos acusados (art. $5^{\circ}, \mathrm{LV}, \mathrm{CRFB}$ ) e a presunção de inocência (art. $5^{\circ}$, LVII, CRFB).

Diante da enorme variedade de princípios e institutos que interferem na dinâmica da aplicação do Direito Penal, optou-se por analisar o princípio da legalidade (art. $5^{\circ}$, II e XXXIX, CRFB), da culpabilidade (art. 59 do Código Penal), da proporcionalidade (decorrente do art. $1^{\circ}$, caput e art. $5^{\circ}, \mathrm{LV}$ da CRFB), da individualização da pena (art. $5^{\circ}, \mathrm{XLVI}, \mathrm{CRFB}$ ) e o instituto do crime continuado (art. 71 do Código Penal). A escolha pela análise dos quatro princípios e do instituto da continuidade delitiva decorre da possibilidade de a incorporação desses temas pelo Direito Administrativo Sancionador produzir efeitos positivos imediatos na realidade punitiva da Administração.

Conforme se verá no tópico adiante, a legalidade orienta a atividade sancionatória da Administração, assim como a cominação de tipos penais, ainda que de forma mais intensa em relação a esses últimos. A proporcionalidade norteia as decisões administrativas em geral, bem como a aplicação de penalidades administrativas no âmbito de relações de sujeição com o Poder Público. A culpabilidade, a individualização da pena e o crime continuado apontam para a gradação das sanções administrativas. As alterações introduzidas pela Lei nº 13.655/2018 à Lei de Introdução às Normas do Direito Brasileiro indiretamente reforçam a culpabilidade por meio do instituto do "erro grosseiro". 


\section{LIMITES E POSSIBILIDADES DE TRANSPOSIÇÃO DE INSTITUTOS DE DIREITO PENAL PARA O DIREITO ADMINISTRATIVO SANCIONADOR}

A partir da premissa da existência de uma unidade do ius puniendi estatal, na medida em que tanto as sanções administrativas quanto as penais são aplicadas pelo Estado, é perfeitamente possível vislumbrar a transposição de alguns dos princípios constitucionais e institutos aplicáveis do Direito Penal para o Direito Administrativo Sancionador. O objetivo desse transplante é assegurar a contenção do arbítrio e dos excessos na atuação administrativa sancionatória, à semelhança do que já ocorre no âmbito penal.

Ao analisarem a relevância de alguns institutos de contenção do arbítrio punitivo estatal, Flávio Amaral Garcia e Diogo de Figueiredo Moreira Neto destacam a necessidade de preceitos universais em matéria de direito sancionador, verbis:

\footnotetext{
"Esses princípios e garantias ganharam tal amplitude ético-jurídica que passaram a reger e a orientar toda e qualquer expressão de poder estatal sancionador, deles derivando-se legítimos mecanismos, à disposição dos indivíduos, para a contenção do exercício indevido do ius puniendi estatal que, sem essas barreiras de proteção, fatalmente retornaria às indesejáveis práticas do arbítrio que antecederam o próprio Estado de Direito" (MOREIRA NETO; GARCIA, 2013).
}

Cumpre iniciar o exame do princípio da legalidade em suas diversas acepções no Direito Penal e no Direito Administrativo.

\subsection{LEGALIDADE: RESERVA LEGAL ESTRITA E LEGALIDADE ADMINISTRATIVA}

O princípio da legalidade caracteriza-se como um dos mais relevantes institutos do Direito Penal. A compreensão de que maneira e em que medida esse direito fundamental que proíbe a punição retroativa deve ser estendido ao Direito Administrativo Sancionador é um dos tópicos que se pretende analisar.

Primeiramente, será traçada a concepção do princípio da legalidade no âmbito do Direito Penal para, em seguida, se abordar a legalidade administrativa à luz da atividade sancionatória da Administração Pública.

Podemos dizer que a sua raiz histórica se encontra no art. 39 da Magna Carta inglesa, de João Sem Terra, de 1215 (JESUS, 2014, p. 104). Tal princípio foi desenvolvido por diversos filósofos como Locke, Montesquieu, Rousseau, Beccaria até se chegar ao Código Penal da 
Baviera (de 1813), redigido por Paul Johann Anselm von Feuerbach, que cunhou a expressão latina: nullum crimen nulla poena sine lege (SOUZA; JAPIASSÚ, 2015, p. 88-89).

No direito brasileiro, o princípio se encontra previsto tanto na legislação infraconstitucional, no art. $1^{\circ}$ do Código Penal, quanto na Constituição, no art. $5^{\circ}$, inciso XXXIX, que praticamente repete a expressão do jurista alemão, "não há crime sem lei anterior que o defina, nem pena sem prévia cominação legal". Nesse ponto, Gilmar Mendes e Paulo Gonet Branco explicam que "a prática de um ato, ainda que reprovável de todos os pontos de vista, somente poderá ser reprimida penalmente se houver lei prévia que considere a conduta como crime" (2015, p. 495).

Esta previsão gera quatro consequências para a dogmática penal: proibição da analogia (exigência de lege stricta); proibição da utilização do costume para fundamentar ou agravar a pena (lege scripta); proibição da retroatividade da lei penal (lege praevia); proibição de incriminações vagas e indeterminadas (lege certa) (SOUZA; JAPIASSÚ, 2015, p. 90-91).

A exigência de lege praevia também está prevista no texto constitucional, no referido artigo, no inciso XL “a lei penal não retroagirá, salvo para beneficiar o réu”.

Além destes requisitos, há, também, o princípio da legalidade formal. A nossa Constituição atribui privativamente à União a competência para a edição desta lei prévia (art. 22, inc. I da CR), através do Congresso Nacional (art. 48 da CR), observados os procedimentos constitucionais do processo legislativo (arts. 59 e ss. da CR) (ZAFFARONI; BATISTA; ALAGIA; SLOKAR, 2003, p. 201-202).

Esse princípio é completado pelo princípio geral da legalidade ou princípio de reserva ou, ainda, princípio da "legaliteralidade" (MIRANDA, 1971, p. 1 apud. ZAFFARONI; BATISTA; ALAGIA; SLOKAR, 2003, p. 202). Estampado no art. $5^{\circ}$, inciso II, da Constituição de 1988, dele decorre que "ninguém será obrigado a fazer ou deixar de fazer alguma coisa senão em virtude de lei".

O cumprimento do princípio da legalidade pressupõe, assim, a edição da norma penal com a maior clareza e precisão possíveis pelo legislador, o que decorre do princípio da máxima taxatividade legal e interpretativa ou determinabilidade ou precisão do tipo penal (lex certa). Tal princípio deve guiar, também, o intérprete, por meio de uma proibição absoluta da analogia in malam partem, porque, se somente a lei formal pode ser fonte de criminalização primária, não pode o juiz complementá-la (ZAFFARONI; BATISTA; ALAGIA; SLOKAR, 2003, p. 208209), criando, assim, um crime sem lei prévia que determina precisamente os contornos da conduta típica. 
O tipo precisa prever exatamente a caracterização do ilícito, bem como a respectiva pena que lhe é cominada. Essa forma de abordagem deve guiar o intérprete da norma, pois não se pode criar um crime sem lei prévia que determine precisamente os contornos da conduta típica e antijurídica punível. A adoção de uma interpretação exemplificativa da legalidade na seara penal poderia conduzir a uma realidade distópica, em que os cidadãos são privados do seu direito de ir e vir sem saber exatamente por que ou por qual crime estão sendo acusados.

Sob outro prisma, o alcance do princípio da legalidade na esfera administrativa sancionadora é distinto em relação ao Direito Penal. Ainda que as punições aplicadas pela Administração Pública devam vir acompanhadas de garantias aos administrados, a fim de evitar arbitrariedades e supressão de direitos fundamentais, a concepção da máxima taxatividade do Direito Penal não comporta transposição para o Direito Administrativo Sancionador.

O princípio da intervenção mínima oriundo da seara penal (GRECO, 2000, p. 53) se presta à proteção de bens jurídicos considerados de maior relevância pela ordem social, (TANGERINO, 2016, p. 125), como a vida e a integridade física. As penas cominadas importam, na maior parte das vezes, em privação da liberdade dos condenados. A sanção administrativa não enseja a privação de liberdade, e não é guiada pelos preceitos morais inerentes à sanção penal. A reprovabilidade da conduta está ligada ao descumprimento de deveres decorrentes de vínculo com a Administração Pública, e não de uma reprovação moral por si só da conduta.

Ao revés, o direito administrativo sancionador deve focar na criação de incentivos aptos a conformar a conduta dos cidadãos a comportamentos socialmente desejáveis, em atenção ao interesse público em cada caso (VORONOFF, 2018, p. 218). Enquanto os ilícitos administrativos têm caráter eminentemente dissuasório e prospectivo, os tipos penais têm um prioritário caráter retributivo e retrospectivo. Por essa razão, a legalidade estrita, caracterizada pela reserva de lei formal e absoluta não é compatível com o Direito Administrativo Sancionador. No dizer de Alice Voronoff:

Esse padrão rigoroso de legalidade não se estende ao direito administrativo sancionador. Em primeiro lugar, porque não há na Constituição a previsão de reserva legal específica, nos moldes da penal, para a instituição de infrações e sanções administrativas. E não se pode interpretar de modo extensivo a reserva absoluta do art. $5^{\circ}$, XXXIX, para sustentar uma limitação implicitamente pretendida pelo constituinte. As hipóteses reservadas pela Constituição à lei em caráter absoluto são restrições severas ao exercício do poder normativo pelo Poder Executivo. Não há como interpretá-las de modo expansivo, sem incorrer em violação ao específico arranjo instituído pelo constituinte em matéria de separação de poderes (VORONOFF, 2018, p. 217). 
No mesmo sentido, Eduardo Sens dos Santos sustenta que:

A imprescindível legalidade estrita do tipo penal (art. 50, XXXIX, da Constituição) - justificável em face da importância do bem protegido: a liberdade - não parece ser absolutamente necessária à configuração dos tipos administrativo-penais (SANTOS, 2004)

Essa solução prestigia o princípio da legalidade no âmbito da atuação administrativa, sem desrespeitar suas peculiaridades.

Ao estipular que "ninguém será obrigado a fazer ou deixar de fazer alguma coisa senão em virtude de lei", o art. 5º II, da Constituição de 1988 explicita a relação entre liberdade e legalidade. Ingo Sarlet, Guilherme Marinoni e Daniel Mitidiero destacam o papel do princípio da legalidade como um instrumento para preservar a liberdade, verbis:

\begin{abstract}
A legalidade também representa a existência e a permanência da ordem jurídica do Estado, edificada por um corpo coeso de normas, organismos e procedimentos que funcionam como garantias constitucionais da liberdade dos cidadãos. No Estado de Direito, a liberdade somente é assegurada mediante uma série de garantias constitucionais calcadas na organização política e administrativa dos poderes, de acordo com as leis e a Constituição (SARLET; MARINONI; MITIDIERO, 2017, p. 489).
\end{abstract}

O princípio da legalidade é orientado para proteger a autonomia da vontade individual, cuja atuação somente poderá ser restringida mediante os limites previstos em lei (BARCELLOS, 2018, p. 146). Na seara do Direito Administrativo, o princípio da legalidade não pode ser encarado de forma tão rigorosa a ponto de ser restringido aos atos emanados do Poder Legislativo.

Historicamente, o princípio da legalidade administrativa foi concebido a partir da conjugação entre o Estado Liberal de Direito e a separação de poderes (BAPTISTA, 2018, p. 76). A teoria da separação dos poderes surgiu da insurgência contra o absolutismo monolítico que imperava na Europa nos séculos XVII e XVIII. A partir da Revolução Francesa de 1789, o pensamento liberal iluminista era de que a lei era produto da razão, capaz de regular todo e qualquer assunto relevante (ARAGÃO, 2001, p. 113; BINENBOJM, 2008, p. 126).

Com isso, administrar era aplicar a lei de ofício. Essa foi a concepção clássica do princípio no direito administrativo brasileiro, segundo as lições de Hely Lopes Meirelles (MEIRELLES, 1985, p. 82/83)

Após a Segunda Guerra Mundial, surgiu o Estado Social de Direito. A degradação humana sofrida com as duas guerras começava a ser recomposta, por meio de atividades prestacionais de Estado. O Estado provisional buscava garantir os direitos sociais da coletividade e corrigir desigualdades sociais históricas. O nascimento dessa acepção de justiça 
social colaborou para a erosão do princípio da legalidade. Afinal, constatou-se que a lei pode legitimar barbaridades, como no Terceiro Reich alemão (BINENBOJM, 2008, p. 129).

Indo além, a professora Patrícia Baptista aponta razões de ordem política que levaram à superação do princípio da legalidade:

\begin{abstract}
Ao lado desse fator de ordem jurídico-filosófica, razões políticas também explicam a existência de uma crise da lei no Estado contemporâneo. (...) Em primeiro lugar, porque as maiorias parlamentares, frequentemente, limitam-se a representar as diversas categorias de interesses sociais com capacidade para influir no processo político. (..) Além do mais, é fato que o processo legislativo, mundo afora, vem sendo amplamente dominado pelo Executivo, seja através das reservas de iniciativa para a apresentação de projetos nas principais matérias, seja pela formação de amplas bases de sustentação parlamentar do Governo que, por meios legítimos oi não, garantem a aprovação de projetos governamentais. (BAPTISTA, 2018, p. 77-78)
\end{abstract}

Ainda, o Estado passou a assumir atividades complexas em um ambiente extremamente dinâmico, que exige soluções rápidas e técnicas por parte da Administração Pública, as quais não se compatibilizam com o vagar do processo legislativo ordinário (SANTOS, 2004; MENDONÇA, 2017, p. 169-189; BAPTISTA, 2018, p. 78; ARAGÃO, 2001, p. 118). A intervenção do Estado no domínio econômico, por meio de empresas estatais em regime de concorrência com a iniciativa privada, e a concessão de fomento público para setores econômicos são apenas alguns exemplos.

Outra razão para a crise da lei em sentido formal no Estado Contemporâneo é o fenômeno da constitucionalização do direito administrativo. Segundo Gustavo Binenbojm, " $a$ superioridade formal e a ascendência axiológica da Constituição sobre todo o ordenamento jurídico produzem uma importantíssima modificação no direito administrativo: a lei é substituída pela Constituição como a principal fonte desta disciplina jurídica."” (BINENBOJM, 2008, p. 130). A atuação administrativa passa a ser orientada pelos princípios constitucionais, notadamente o sistema de direitos fundamentais e o sistema democrático (BINENBOJM, 2008, p. 7)

A insuficiência da lei em sentido formal para balizar a atuação administrativa também resulta na proliferação de delegações legislativas (BAPTISTA, 2018, p. 79). Trata-se dos regulamentos (de execução, autônomos ou independentes, previstos pelo art. 84, VI da $\mathrm{CRFB} / 88$ ) e atos executivos equiparáveis às leis, quais sejam as medidas provisórias (art. 84, XXVI, da CRFB/88) e as leis delegadas. São os chamados atos materialmente legislativos, que inovam no ordenamento criando direitos e obrigações aos particulares. 
O princípio da legalidade bifurca-se em dois subprincípios: o da preeminência ou precedência de lei e o da reserva de lei (MAYER, 1949, p. 95 e 98). A precedência de lei impõe que qualquer ato infralegal será inválido, caso confronte com uma lei. Já a reserva de lei "significa que a criação de direitos e obrigações, interferindo na liberdade ou na propriedade das pessoas, apenas pode ser levada a cabo por meio de lei" (BARCELLOS, 2018, p. 147). Este último classifica-se em $(i)$ reserva de lei formal ou material; e (ii) reserva de lei absoluta ou relativa.

A reserva de lei formal significa, conforme já dito, a necessidade de aprovação de lei em sentido estrito. A reserva de lei material, por sua vez, comporta todos os atos legais que tenham conteúdo e força de lei, tais como medidas provisórias ${ }^{4}$ e leis delegadas. Já a reserva de lei absoluta consiste na exigência de que o legislador esgote o tratamento de determinada matéria por meio de lei. Não haveria espaço para a criação normativa posterior mediante edição de regulamentos. A seu turno, a reserva de lei relativa flexibiliza essa espécie de núcleo duro da lei, permitindo que o ato legislativo preveja parâmetros adequados à atuação administrativa, que poderão ser posteriormente complementados por meio de regulamentos criativos. Independentemente do tipo de regulamento a ser editado, seja ele de execução, autônomo, independente ou organizativo, há significativo espaço para uma atuação criativa da Administração Pública, desde que respeitada a habilitação legislativa que autorizou sua atividade (CYRINO, 2018).

No que concerne ao princípio da legalidade administrativa, ele encontra previsão no art. 37, caput, da Constituição da República, sendo aplicável à Administração Pública como um todo. Na concepção tradicional oriunda da doutrina italiana, o indivíduo pode fazer tudo que não lhe é expressamente vedado, enquanto a Administração pode fazer apenas o que a lei expressamente lhe consente.

Uma contemporânea releitura do Direito Administrativo no Brasil reclama a conclusão de que o fundamento da atividade administrativa deve abarcar não apenas leis em sentido formal, mas em todo o ordenamento jurídico, especialmente na Constituição da República. É a chamada juridicidade administrativa (BINENBOJM,2008, p. 141), assim conceituada:

\footnotetext{
${ }^{4}$ Quanto à possibilidade de criação de infrações e sanções administrativas por meio de medida provisória editada pelo Chefe do Executivo, Edilson Pereira Nobre Junior entende que "a precariedade da medida provisória, a submeter a validade definitiva das suas prescrições à posterior conversão em lei, impede que venha operar efeitos no tocante à movimentação, em detrimento do particular, do ius puniendi estatal, ao que não é alheio a função administrativa" (JUNIOR, Edilson Pereira Nobre. Op. cit., p. 134). Em sentido contrário, v. VORONOFF, Alice. Op. cit., p. 236/238.
} 
O princípio da legalidade ganha, assim, a conotação de um princípio da juridicidade. Não sendo possível a inteira programação legal da Administração Pública contemporânea, é forçoso, contudo, mantê-la totalmente subordinada aos princípios e regras do ordenamento jurídico, especialmente do ordenamento constitucional. A atividade administrativa deve haurir seu fundamento diretamente do texto constitucional (BAPTISTA, 2018, p. 83).

A atuação sancionatória da Administração Pública também deve ser lida à luz do princípio da juridicidade, a fim de que sejam resguardados os direitos fundamentais dos administrados. Considerando que a atividade sancionatória é mais gravosa do que as atividades administrativas em geral, isso reclama um "padrão de legalidade mais exigente do que aquele reconhecido ao direito administrativo em geral" (VORONOFF, 2018, p. 231).

Esse padrão de legalidade traduz-se em reserva de lei relativa. A atividade sancionatória pressupõe a edição de lei em sentido formal que preveja parâmetros orientadores da atividade regulamentar do administrador. Ou seja, atos infralegais não poderão criar sanções com fundamento direto na Constituição, dependendo de lei que habilite o exercício da competência. Assim defende Alexandre dos Santos Aragão:

Integramos a corrente daqueles para quem basta a habilitação legal dos poderes da Administração Pública, sem que a lei precise entrar na matéria, a ser regulada pela Administração Pública. (...)

Não seria suficiente, contudo, apenas a previsão legal da competência da Administração Pública editar normas sobre determinado assunto. Mister se faz que a lei estabeleça também princípios, finalidades, políticas públicas ou standards que propiciem o controle do regulamento (intelligible principles doctrine), já que a atribuição de poder normativo sem que se estabeleçam alguns parâmetros para o seu exercício não se coadunaria com o Estado Democrático de Direito, que pressupõe a possibilidade de controle de todos os atos estatais (ARAGÃO, 2004, p. 58).

Sobre esta temática, é preciso rememorar a doutrina norte-americana dos princípios inteligíveis (intelligible principles doctrine). Ela consiste na ideia básica de que a lei deve estabelecer standards mínimos em relação aos quais o administrador não pode se afastar, sob pena de inconstitucionalidade. A referida teoria ganhou prestígio com a flexibilização da clássica nondelegation doctrine pela Suprema Corte norte-americana (CYRINO, 2018, p. 81).

No Direito Administrativo Sancionador, a habilitação jurídica conferida pela lei explícita ou implícita, conforme o caso - é necessária para conferir densidade normativa a atos infralegais que prevejam sanções administrativas. No dizer de Valter Shuenquener de Araújo:

a lei deve estabelecer parâmetros mínimos das condutas e das sanções. Em caso de deslegalização, por exemplo, o legislador deve, no mínimo, estabelecer os parâmetros capazes de identificar quais são as infrações a serem reprimidas pelo administrador e as possíveis sanções (ARAÚJO, 2019, p. 442). 
A lei prévia deve existir e estipular as diretrizes e limites para a aplicação de sanções administrativas (ARAÚJO, 2019, p. 442; VORONOFF, 2018, p. 231). Nessa perspectiva, a intenção do legislador de atribuir competência ao Poder Executivo para detalhar tipos administrativos ou para especificar sanções deve ser expressa e estar clara no texto legal.

\subsection{CULPABILIDADE}

No Direito Penal, a culpabilidade se bifurca em culpabilidade em sentido estrito, que é elemento integrante do crime, e em sentido lato, caracterizada pela maior ou menor reprovabilidade da conduta antijurídica do agente.

A culpabilidade em sentido lato é definida por Cezar Roberto Bittencourt como " $a$ reprovação pessoal que se faz contra o autor pela realização de um fato contrário ao Direito, embora houvesse podido atuar de modo diferente de como o fez" (BITTENCOURT, 2007, p. 343). É a culpabilidade que preceitua a reprovabilidade da conduta do agente como um critério regulador da pena (GRECO, 2000. p. 84-85). Não sem motivo, a culpabilidade é o primeiro critério a ser observado pelo juiz no momento da fixação da pena-base, conforme dispõe o art. 59 do CP.

A culpabilidade em sentido estrito, a seu turno, é fundamental para a conclusão de que apenas há crime quando existe dolo ou culpa. Assim, a responsabilização de pessoas físicas no Direito Penal deveria ser subjetiva, conclusão que também se extrai do brocardo latino nullum crimen sine culpa. Daí o artigo 18 do $\mathrm{CP}$ determinar que são puníveis apenas as condutas dolosas, salvo previsão legal em sentido contrário. Mas essa regra não é absoluta, diante da previsão de responsabilidade objetiva no art. 28 , II do CP que determina que a embriaguez, voluntária ou culposa, não exclui a imputabilidade penal. ${ }^{5}$

A doutrina estrangeira percorre certa ressignificação do princípio da culpabilidade, afastando-o da concepção clássica de reprovabilidade da conduta (culpabilidade em sentido lato). Aqui filia-se às ideias de Francisco Muñoz Conde, que propõe o conceito material de culpabilidade ou culpabilidade como a teoria do sujeito responsável (MUÑOZ CONDE, 2010), especialmente para fins de aplicação da culpabilidade ao Direito Administrativo Sancionador.

\footnotetext{
${ }^{5}$ A doutrina tradicional de Direito Penal adotava, mesmo nos casos em que não havia preordenação na embriaguez, a teoria da actio libera in causa, ou seja, desde que livre no momento da embriaguez, deve a pessoa responder pelo ato ilícito (HUNGRIA, Nélson. Comentários ao Código Penal. Rio de Janeiro: Forense, 1977. v. 1. t. 2, p. 386 e 388). No entanto, com maestria, Damásio de Jesus leciona que tal norma não fora recepcionada pela Constituição de 1988, tendo em vista o art. $5^{\circ}$, inciso LVII, que consagra o princípio da presunção da inocência até o trânsito em julgado de sentença penal condenatória. Desse modo, a legislação ordinária não poderia presumir dolo ou culpa de quem se embriaga. (JESUS, Damásio de. Op. cit. p. 557).
} 
O entendimento é de que a culpabilidade não está fundada na maior ou menor reprovação da conduta do agente, ligada à imputabilidade penal. A ordem de razão para instituição do ilícito - penal ou administrativo - é a motivação do indivíduo a agir conforme seu comando normativo, abstendo-se de realizar conduta que o contrarie. Para Muñoz Conde:

\begin{abstract}
a tarefa do Estado Social e Democrático de Direito não consiste em castigar os que não estão em condições de poder participar em condições de igualdade na configuração da vida social, senão em promover as condições para que a liberdade e a igualdade do indivíduo e dos grupos em que se integra sejam reais e efetivas; remover os obstáculos que impeçam ou dificultem a plenitude e facilitar a participação de todos os cidadãos na vida política, econômica, cultural e social (MUNOZZ CONDE, 2010, p. 355/356). ${ }^{6}$
\end{abstract}

A capacidade conformativa da norma instituidora do ilícito é que deve, assim, ser considerada no momento da aplicação da sanção. Seja ela de natureza administrativa ou penal, cada qual com suas características de justificação, o que importa fundamentalmente é a promoção de alterações significativas na conduta dos indivíduos, de forma a proporcionar incentivos para uma atuação conforme o direito.

A diferença entre as razões de justificação do ilícito penal e administrativo impede o transplante automático da culpabilidade penal para o direito administrativo sancionador. A concepção clássica da culpabilidade penal adotada pelo legislador ordinário reflete o caráter retributivo da pena, como medida aflitiva pelo descumprimento da norma. A sanção administrativa tem viés dissuasório ${ }^{7}$, mais aproximado da culpabilidade anunciada pela teoria do sujeito responsável de Muñoz Conde. A finalidade é criar incentivos complexos e variáveis para o modo de agir dos particulares, por meio de normas de comando e controle.

Um exemplo ilustrativo são as sanções previstas pela Lei de Licitações e Contratos Administrativos (Lei $\mathrm{n}^{\circ}$ 8.666/1993) Diante do descumprimento de um dever contratual pelo particular contratado, o legislador previu sanções mais ou menos gravosas, que visam coibir o inadimplemento contratual (art. 87 da Lei $\left.\mathrm{n}^{\circ} 8.666 / 93\right)^{8}$. Não se busca ressarcir o erário, mas

\footnotetext{
${ }^{6}$ No original: "la tarea del Estado social y democrático de Derecho no consiste en castigar a los que no están en condiciones de poder participar en condiciones de igualdad en la configuración de la vida social, sino en «promover las condiciones para que la libertad y la igualdad del individuo y de los grupos en que se integra, sean reales y efectivas; remover los obstáculos que impidan o dificulten su plenitud y facilitar la participación de todos los ciudadanos en la vida política, económica, cultural y social."

${ }^{7}$ Para uma abordagem histórica das teorias dissuasórias de justificação da pena, v. VORONOFF, 2018, p. 82-88.

${ }^{8}$ Art. 87. Pela inexecução total ou parcial do contrato a Administração poderá, garantida a prévia defesa, aplicar ao contratado as seguintes sanções:

I - advertência;

II - multa, na forma prevista no instrumento convocatório ou no contrato;

III - suspensão temporária de participação em licitação e impedimento de contratar com a Administração, por prazo não superior a 2 (dois) anos;
} 
assegurar o interesse público subjacente ao contrato administrativo (ESTORNINHO, 2003, p. 128).

No Direito Administrativo Sancionador, a culpabilidade representa a responsabilidade pessoal do administrado pela prática da conduta antijurídica. É a culpabilidade em sentido estrito, que atrai como elementos do tipo a conduta dolosa ou culposa, a título de negligência, imprudência ou imperícia.

Não há como escapar da máxima, já sedimentada no Direito Penal, de que o agente responde, ao menos, a título de culpa, ou, de acordo com o que prevê o art. 28 da Lei de Introdução às Normas do Direito Brasileiro (LINDB), introduzido pela Lei $\mathrm{n}^{\circ}$ 13.655/2018, desde que existente erro grosseiro.

Sobre o tema, Rafael Munhoz de Mello defende que:

Tratando-se de princípio constitucional, (...) o legislador infraconstitucional não pode afastar a culpabilidade do campo do direito administrativo sancionador, outorgando à Administração Pública competência para impor sanções administrativas retributivas independentemente da culpa do particular (MELLO, 2005).

Marçal Justen Filho também defende a aplicação do princípio da culpabilidade nas sanções administrativas, verbis:

O Estado Democrático de Direito exclui o sancionamento punitivo dissociado da comprovação da culpabilidade. Não se pode admitir a punição apenas em virtude da concretização de uma ocorrência danosa material. Pune-se porque alguém agiu mal, de modo reprovável, em termos antissociais. A comprovação do elemento subjetivo é indispensável para a imposição de penalidade, ainda quando se possa pretender uma objetivação da culpabilidade em determinados casos (JUSTEN FILHO, 2014, p. 607).

Essa mesma linha é adotada por parte expressiva da doutrina. ${ }^{9}$ Todavia, a reprovabilidade da conduta do agente - referida como culpabilidade em sentido estrito não é o único e nem pode ser o mais relevante parâmetro para a aplicação da sanção administrativa. É que, no momento da quantificação da sanção administrativa, também devem ser considerados os critérios objetivos definidos em lei.

IV - declaração de inidoneidade para licitar ou contratar com a Administração Pública enquanto perdurarem os motivos determinantes da punição ou até que seja promovida a reabilitação perante a própria autoridade que aplicou a penalidade, que será concedida sempre que o contratado ressarcir a Administração pelos prejuízos resultantes e após decorrido o prazo da sanção aplicada com base no inciso anterior.

${ }^{9}$ Em sentido contrário, associando a tipicidade da conduta antijurídica à mera voluntariedade da atuação do agente, v. DE MELLO, Celso Antonio Bandeira. Curso de Direito Administrativo. 29a edição. São Paulo: Editora Malheiros, 2012, p. 866. FERREIRA, Daniel. Teoria Geral da infração administrativa a partir da Constituição Federal de 1988. Belo Horizonte: Editora Fórum, 2009, p. 288-327. 
A título de exemplo, o artigo 22, $\S 1^{\circ}$, da Lei no 13.655/2018 prevê que: "Na aplicação de sanções, serão consideradas a natureza e a gravidade da infração cometida, os danos que dela provierem para a administração pública, as circunstâncias agravantes ou atenuantes e os antecedentes do agente".

Em outras palavras, são esses os critérios objetivos gerais a serem considerados na aplicação de sanções, seja em relação aos administrados, no exercício do poder de polícia ou aos servidores públicos, nos liames do seu vínculo funcional (poder disciplinar). E fez bem a Lei $\mathrm{n}^{\circ} 13.655 / 2018$ ao explicitar os critérios de dosimetria das sanções administrativas, sem relegar a imposição das mesmas ao subjetivismo puro do gestor público (JORDÃO, 2018, p. 84-85; ARAÚJO, 2019, p. 444).

A boa fé e a diligência do administrado são relevantes e devem ser aferidas por parâmetros claros e objetivos, definidos de lege data. Seguindo essa linha, Margarida Ermelinda Linda Morais de Faria sustenta que:

Com efeito, a culpa, ou melhor, a negligência do administrado, é presumida na ausência de defesa por parte deste, com fundamento na violação do dever geral de cuidado que a prática da infracção por si só consubstancia. O elemento subjectivo acaba por se presumir, influindo na determinação da medida da sanção apenas os critérios objectivos definidos na lei (reincidência, situação económica do infractor, etc.). O caso muda de figura quando o infractor exerce o seu direito de defesa, alegando nomeadamente causas de justificação, caso em que a Administração deve avaliar o seu grau de culpa, sendo o resultado dessa avaliação critério determinante para a decisão administrativa final(FARIA, 2007, p. 117/118).

Como fundamento adicional à transposição temperada do princípio da culpabilidade ao Direito Administrativo Sancionador, tem-se a admissão excepcional da responsabilidade objetiva, tal como prevista no art. $1^{\circ}$ da Lei no 12.846/2013 (Lei Anticorrupção).

Em suma, o princípio da culpabilidade é aplicável ao Direito Administrativo Sancionador por duas razões. A culpabilidade concebida pela teoria do sujeito responsável de Muñoz Conde atende à natureza dissuasória da sanção administrativa. A culpabilidade também figura como elemento caracterizador do ilícito administrativo, especialmente em relação à responsabilidade pessoal de servidores.

Ficam ressalvadas aquelas hipóteses excepcionais em que o legislador comina sanções para pessoas jurídicas nas situações em que, por razões de política pública, a responsabilidade objetiva se revela fundamental para o fortalecimento do caráter preventivo da punição em uma matéria específica, tal como no caso do combate à corrupção. 


\subsection{PRINCÍPIO DA PROPORCIONALIDADE}

No Direito, deve haver uma justa proporção entre a gravidade de uma conduta e a sanção para ela cominada. As penas previstas para os crimes contra a vida, por exemplo, devem ser superiores às definidas para os crimes contra a propriedade (ZAFFARONI; BATISTA; ALAGIA; SLOKAR, 2003, p. 231). Ao exigir que a pena cominada deve ser proporcional ao bem jurídico lesado e à própria violação provocada, o princípio da proporcionalidade acaba por, também, guardar relação direta com o instituto do crime continuado.

O emprego da proporcionalidade em situações de continuidade delitiva ocorre por uma razão simples. A ausência de uma construção lógica como a existente no Direito Penal em torno do crime continuado acarretaria situações inexplicáveis em que o somatório das penas de crimes de menor gravidade atingiria o mesmo patamar que o de crimes de maior reprovabilidade. Em outras palavras, não faria sentido aplicar a um indivíduo que, mediante seis ações pratica seis crimes de furto em continuidade delitiva, uma pena semelhante à de um indivíduo que comete homicídio.

Há quem entenda que a proporcionalidade entre ato e pena é originariamente um instituto típico do Direito Penal ${ }^{10}$, conhecido desde os tempos do direito penal hebreu, que tinha como uma das características o talião:

Segundo alguns juristas e teólogos medievais e posteriores, o talião possuía um sentido puramente metafórico, indicando a proporcionalidade da pena, enquanto, para outros, o "olho por olho, dente por dente, sangue por sangue" tinha um sentido literal e assim foi aplicado pelos hebreus. (g.n.) (ZAFFARONI; PIERANGELI, 2004, p. 178).

É oportuno rememorar que o princípio da proporcionalidade encontra fundamento constitucional, ainda que a doutrina não seja uníssona quanto ao específico dispositivo que o ampara. Por todos, Gilmar Ferreira Mendes e Paulo Gonet Branco sintetizam que:

Vozes eminentes sustentam que a base do princípio da proporcionalidade residiria nos direitos fundamentais. Outros afirmam que tal postulado configuraria expressão do Estado de Direito, tendo em vista também o seu desenvolvimento histórico a partir do Poder de Polícia do Estado. Ou ainda, sustentariam outros, cuidar-se-ia de um postulado jurídico com raiz no direito suprapositivo (MENDES, GONET BRANCO, 2015, p. 218).

Independentemente da localização topográfica do seu fundamento, a proporcionalidade é um princípio constitucional implícito, admitido por força tanto do art. $5^{\circ}, \S 2^{\circ}$, da CRFB/88,

${ }^{10}$ Outra parcela da doutrina admite a pena no âmbito do Direito Civil, por meio dos chamados "punitive damages". Há forte discussão acerca da matéria. Nesse sentido, v. SCHREIBER, 2018, p. 631 
que prevê um catálogo aberto de direitos fundamentais, quanto em razão do Estado de Direito (SARLET; MARINONI; MITIDIERO, 2017, p. 766/767), ou até mesmo do devido processo legal substantivo (BARCELLOS, 2018, p. 162). No âmbito infraconstitucional, o artigo $2^{\circ}$, caput e o seu parágrafo único, VI, da Lei $\mathrm{n}^{\circ}$ 9.784/99 trataram de prevê-lo expressamente, de modo a coibir o excesso na atuação administrativa, notadamente quando se estiver diante de obrigações, restrições e sanções.

Qualquer ação estatal que restrinja os direitos e interesses fundamentais dos indivíduos deve, portanto, passar pelo exame da proporcionalidade, que engloba três testes sucessivos: (i) adequação da norma ou ato restritivo à consecução das finalidades que se pretende concretizar; (ii) necessidade ou vedação do excesso, que impõe que a medida seja a menos restritiva possível dentre outros meios possíveis, (iii) proporcionalidade em sentido estrito, que comporta o confronto da norma com o restante do sistema constitucional, num controle de sintonia fina e de justeza com a ordem jurídica como um todo (ALEXY, 2008. p. 110; ÁVILA, 2016, p. 209; PEREIRA, 2018, p. 377).

O comando da vedação ao excesso tem especial aplicação ao Direito Administrativo Sancionador. Sob o aspecto da necessidade, é preciso aferir se a medida punitiva prevista em lei é aquela que acarreta menos sacrifícios para os destinatários e para a sociedade dentre as alternativas existentes para se alcançar o objetivo da sanção. O subprincípio da adequação, por sua vez, impede que a escolha da sanção administrativa e a fixação do seu quantum se realize sem uma preocupação com os fins que a medida deve alcançar. No que diz respeito à proporcionalidade em sentido estrito, deve se ter em mente a relação de custo benefício entre os resultados positivos que a medida punitiva produz e os seus efeitos deletérios. Isso pode ser fundamental, por exemplo, em matéria de concorrência quando, pelo excesso, a sanção puder eliminar um dos concorrentes em uma atividade econômica específica.

O fundamento da vedação do excesso na seara da atividade sancionatória do Estado não é o mesmo, portanto, daquele aplicável às demais áreas do direito administrativo. A aplicação de sanções importa restrições mais gravosas a direitos e a patrimônio de particulares específicos. As atividades administrativas em geral são prestadas a toda a coletividade, que suporta danos normais e inespecíficos. A coletivização dos riscos sociais exige que os particulares suportem os ônus gerados pela atividade administrativa, a fim de resguardar o interesse da coletividade. Daí a proposição de uma incidência individual da proporcionalidade, que balize a aplicação da sanção, mais aproximada da proporcionalidade penal. Marcelo Prates sugere dois standards para a aplicação da proporcionalidade na atuação sancionatória do Estado 
(PRATES, 2003, p. 124-125). O primeiro se refere à necessidade de os direitos e liberdades restringidos estarem sujeitos à órbita de controle e intervenção das autoridades administrativas. O segundo critério exige que haja correspondência direta entre o tipo delitivo e a sanção administrativa aplicável. No mesmo sentido, Diogo Moreira de Figueiredo Neto e Flávio Amaral Garcia sustentam que:

No campo do Direito Administrativo Sancionador, a norma deve, obrigatoriamente, estabelecer tipos delitivos que guardem correlação lógica com a aplicação de sanções que sejam proporcionais aos ilícitos administrativos cometidos ou, expresso de outra forma, tipos que correspondam a condutas que efetivamente revelem desconformidade com bens jurídicos merecedores de proteção (MOREIRA NETO; GARCIA, 2013).

Em se tratando de leis de baixa densidade normativa, que banalizam o emprego de conceitos jurídicos indeterminados ou estabelecem um vasto cardápio de sanções para cada infração cometida, há maior espaço para o administrador público. Essa maior liberdade está sujeita a um controle mais intenso, seja ele administrativo ou jurisdicional, o que pode ser feito com lastro na proporcionalidade.

Dessa forma, caso a lei ranqueie um parâmetro mínimo e máximo de aplicação da pena, a proporcionalidade impõe a previsão - explícita ou implícita, conforme o caso - de critérios objetivos para a maximização ou minimização do quantum da sanção administrativa. Há, assim, relação direta entre o princípio da proporcionalidade e o da individualização da pena.

\subsection{PRINCÍPIO DA INDIVIDUALIZAÇÃO DA PENA}

O princípio da individualização da pena encontra-se positivado na Constituição da República em seu artigo $5^{\circ}$, inciso XLVI, verbis:

XLVI - a lei regulará a individualização da pena e adotará, entre outras, as seguintes:

a) privação ou restrição da liberdade;

b) perda de bens;

c) multa;

d) prestação social alternativa;

e) suspensão ou interdição de direitos;

Para Guilherme Nucci, o princípio da individualização da pena:

significa a concretização da justiça de se atribuir a cada um o que é seu, a cada um o que efetivamente merece, valendo-se, pois, da culpabilidade do fato e da culpabilidade do autor, está esgotando-se igualmente no fato (NUCCI, 2005. p. 389). 
Conforme Rogério Greco, o primeiro momento da individualização da pena ocorre na fase de criação da lei, ocasião em que são escolhidas quais condutas serão puníveis pelo Direito Penal. Após esta escolha, o legislador atribui penas variadas conforme a importância do bem jurídico tutelado, já na chamada fase de cominação (GRECO, 2000, p. 71).

Na sequência, ocorre a aplicação da pena, em que será fixada a pena-base, a partir dos critérios elencados pelo art. 59 do CP. Daí serão consideradas, caso existam, as circunstâncias atenuantes ou agravantes. Nesse momento, o juiz individualiza as sanções de cada condenado, estabelecendo (i) as penas aplicáveis; (ii) a quantidade de pena cominada; (iii) o regime inicial de cumprimento de pena; e (iv) a substituição da pena privativa de liberdade por outra, se cabível (MENDES; GONET BRANCO, 2015, p. 530). Ao final, as causas de diminuição ou de aumento de pena (art. 68 do Código Penal). Há, ainda, uma terceira fase de execução da pena, conforme previsto no art. $5^{\circ}$ da Lei n ${ }^{\circ} 7.210 / 84$ (Lei de Execução Penal). ${ }^{11}$

O princípio da individualização da pena traduz-se em verdadeiro direito fundamental do condenado e, a fortiori, também deve ser observado pelo administrador público no momento em que escolhe e quantifica a sanção administrativa. Sobre o tema, Eduardo Sens dos Santos adota o entendimento, que se comunga, da necessidade de a lei fixar os parâmetros para a individualização da sanção, ainda que de forma aberta, verbis:

há de haver expressa previsão, mesmo que ampla, das normas principais do instituto em lei em sentido formal, como já decidiu o Supremo Tribunal Federal, além, é claro, de não ser a matéria de veiculação reservada à lei. Sem isso, não se teria relativização do princípio da legalidade, mas simples abandono (SANTOS, 2004).

Por certo, o particular não pode ser surpreendido com a aplicação de sanção decorrente de suposta infração administrativa não prevista no ordenamento quando da sua ocorrência. Isso ofenderia o princípio da proteção da confiança, dimensão subjetiva da segurança jurídica (ARAÚJO, 2016). O direito sancionador nada tem de peculiar que justifique o desprezo à tutela de expectativas legítimas daquele que é infrator. O cidadão, ainda que atue em desconformidade com o ordenamento jurídico, projeta-se em um espaço de previsibilidade que deve ser respeitado pelo Estado, inclusive no que concerne à aplicação de sanções. Assim, a precedência de lei e a reserva de lei são institutos seculares que prestigiam e reforçam o princípio da proteção da confiança.

11 Art. $5^{\circ}$ Os condenados serão classificados, segundo os seus antecedentes e personalidade, para orientar a individualização da execução penal. 
Uma vez definidas em lei as possíveis sanções administrativas aplicáveis, o ato infralegal respectivo que a regulamentar pode tratar da sua quantificação à luz de critérios objetivos acerca da conduta infratora e diante das circunstâncias do caso concreto. Não se trata de abstração jurídica, mas de lógica que prestigia a reserva de lei relativa em matéria sancionatória, e a capacidade criativa da competência normativa da Administração Pública.

Atendida a exigência de reserva de lei relativa para previsão das sanções administrativas, o princípio da individualização da pena incidirá no momento da quantificação e qualificação da sanção em relação ao administrado ou servidor público. No âmbito do processo administrativo disciplinar, quando a autoridade competente enfim deliberar pela aplicação da sanção. Nos contratos administrativos, quando se constatar o inadimplemento total ou parcial do particular contratado. No exercício do poder de polícia, na etapa de fiscalização da sanção de polícia.

A incidência do princípio da individualização da pena no direito administrativo sancionador orienta a quantificação da penalidade pelo administrador, de forma similar à etapa de aplicação da pena na seara penal. Há parâmetros objetivos para quantificação da sanção previstos em lei, de forma semelhante ao direito penal. Isto é, desde que observado o contraditório e o processo administrativo prévios, de modo que a decisão administrativa que opte pela sanção indique diretamente a correlação entre a conduta do particular e a sanção a ele aplicada.

\subsection{CRIME CONTINUADO (ARTIGO 71 DO CÓDIGO PENAL)}

O instituto do crime continuado encontra-se previsto no artigo 71 do Direito Penal e, em breve síntese, tem emprego quando o agente pratica mais de um crime com características comuns (mesma espécie, condições de tempo, lugar, maneira de execução e outras semelhantes). Neste caso, o cálculo da pena final não será feito com base no somatório das penas de todos os crimes. Aplicar-se-á a pena de um crime, se idênticos, ou do mais grave se distintos, com um aumento da pena de um sexto a dois terços, verbis:

Artigo 71 - Quando o agente, mediante mais de uma ação ou omissão, pratica dois ou mais crimes da mesma espécie e, pelas condições de tempo, lugar, maneira de execução e outras semelhantes, devem os subsequentes ser havidos como continuação do primeiro, aplica-se-lhe a pena de um só dos crimes, se idênticas, ou a mais grave, se diversas, aumentada, em qualquer caso, de um sexto a dois terços. 
É cediço que o dispositivo acima possui larga aplicação no Direito Penal. Entretanto, as leis e atos normativos que veiculam regras sobre sanções administrativas não preveem, ao menos expressamente, dispositivo semelhante ao do art. 71 do Código Penal. De todo modo, essa lacuna aparente não pode impedir que a ratio gravitante em torno do crime continuado também seja utilizada pela Administração Pública quando estiver no exercício da atuação sancionadora.

As modalidades de sanções aplicáveis e as penas devem estar previstas em lei. Por outro lado, são as circunstâncias do caso concreto, verificadas na continuidade de uma mesma infração pelo administrado, em situações de tempo e lugar similares, que impõem ao administrador o dever de forçar a inovação (MENDONÇA, 2017). Portanto, no afã de tornar a pena justa e proporcional no caso concreto, o administrador pode construir uma dosimetria permeada pela lógica da continuidade delitiva. Ainda que não exista uma lei expressa o autorizando, razões de segurança jurídica, justiça e proporcionalidade justificam/legitimam a aplicação pela Administração Pública de uma única pena prevista para a infração com a majoração dentro das mesmas balizas do Código Penal. A continuidade delitiva é, assim, medida que pode ser adotada no direito sancionador mesmo na ausência de previsão legal expressa no âmbito administrativo.

Sob outro enfoque, condicionar o reconhecimento da aplicação da dinâmica do crime continuado no âmbito do Direito Administrativo Sancionador à edição de lei expressa prevendo o referido instituto pode acarretar, em alguns casos, um excesso de punição ao infrator capaz de inviabilizar a concorrência e o princípio da livre iniciativa, princípios gerais da atividade econômica previstos no artigo 170 da Constituição da República. Assim, negar aplicação ao instituto da continuidade delitiva no Direito Sancionador brasileiro com fundamento em uma distorcida e anacrônica compreensão do princípio da legalidade estrita, impede a concretização da justiça, torna o sistema punitivo irracional, viola a proporcionalidade da sanção, e dificulta o caráter dissuasório da sanção administrativa.

\section{CONCLUSÃO}

1. O Direito Penal e o Direito Administrativo, em seu viés sancionador, encontram origens históricas e estágios de evolução diferenciados. Enquanto o primeiro já se situa em um momento de maturidade avançado em relação a seus institutos, o segundo tem raízes históricas mais recentes, datadas do século XVIII. Essa constatação, associada à ideia da existência de 
unidade do ius puniendi estatal, nos permite reconhecer a necessidade de pesquisa sobre em que medida institutos do Direito Penal podem ser transplantados para o Direito Administrativo Sancionador.

2. Os ilícitos administrativos se inserem na atuação conformadora da Administração Pública, que visa à criação de um sistema de incentivos aos cidadãos e à realização de interesses socialmente relevantes. O ilícito penal, por sua vez, a despeito de também ser criado legalmente com um olhar para a prevenção, ostenta um forte caráter retributivo e produz efeitos sancionatórios nitidamente mais gravosos, o que se constata pela possibilidade de privação da liberdade do condenado.

3. A transposição de institutos e princípios constitucionais aplicáveis ao Direito Penal para o Direito Administrativo Sancionador é recomendável, mas não deve ser automática e acrítica.

4. O princípio da legalidade se aplica ao Direito Administrativo Sancionador com um rigor diverso daquele exigido no âmbito do Direito Penal em termos de legalidade estrita. Basta uma habilitação legal suficiente, expressa ou implícita, para a especificação de sanções administrativas por meio de atos infralegais. No Direito Administrativo Sancionador, vigora, assim, a reserva de lei relativa, que permite a delimitação dos contornos das sanções administrativas por meio de atos infralegais.

5. O princípio da culpabilidade pode ser transplantado para o Direito Administrativo Sancionador em sua acepção em sentido estrito. Ao realizar a dosimetria das sanções, o administrador, além de considerar o elemento subjetivo presente na conduta do infrator, também tem o dever de considerar critérios objetivos. Os parâmetros objetivos para a aferição da sanção a ser aplicada estão previstos, por exemplo, no artigo 22 da LINDB. Admitese a conduta antijurídica a título de dolo ou, ao menos, culpa em sentido estrito. O artigo 28 da LINDB, por sua vez, estipula que os agentes públicos apenas serão responsabilizados por opiniões e pareceres a título de dolo ou erro grosseiro, tornando mais difícil a punição de agentes públicos por uma singela negligência, imprudência ou imperícia. Por outro lado, a responsabilidade objetiva tem sido admitida excepcionalmente para punir pessoas jurídicas infratoras, o que se justifica para reforçar o caráter dissuasório do direito sancionador no combate à corrupção.

6. O princípio da proporcionalidade, em conjunto com os seus subprincípios da adequação, necessidade e proporcionalidade em sentido estrito, deve ser aplicado no Direito Administrativo Sancionador, tanto no momento de criação quanto da quantificação/dosimetria 
da sanção administrativa. A escolha da sanção dentre aquelas permitidas pela lei é tarefa que deve observar a proporcionalidade, sob pena de o sistema punitivo estatal tornar-se irracional e injusto. A sanção, que não é um fim em si mesmo, deve ser adequada para punir e prevenir a infração praticada, precisa ser a medida menos gravosa para a sociedade dentre as alternativas existentes e deve ser um preceito que proporciona mais benefícios do que prejuízos para a coletividade (relação de custo-benefício).

7. O princípio da individualização da pena também deve ser transplantado para o Direito Administrativo Sancionador como pressuposto lógico da adoção do princípio da proporcionalidade e da culpabilidade. Nesse sentido, a delimitação da medida da sanção precisa ser individualizada de acordo as circunstâncias do caso concreto e deve, ainda, observar as infrações vigentes no momento em que a conduta fora praticada, sob pena de eventual ofensa ao princípio da proteção da confiança.

8. Ainda que o instituto da continuidade delitiva não esteja previsto expressamente em lei para a esfera do Direito Administrativo Sancionador, ele deve ser aplicado pelo administrador público na quantificação das sanções administrativas. A transposição constitui consectário lógico do princípio da proporcionalidade, vez que não seria proporcional a mera soma das sanções em casos de continuidade delitiva. Nesse caso, o administrador público pode instituir a exasperação da sanção administrativa ainda que esse mecanismo não esteja previsto na lei base, em verdadeira atuação inovadora.

9. Muito embora a transposição para o Direito Administrativo Sancionador de regras e princípios do Direito Penal possa trazer profundos avanços para a tutela dos direitos fundamentais na esfera administrativa, não se pode perder de vista que, no âmbito criminal, muitos dos institutos não se materializam na prática. Como exemplo, podemos citar o princípio da individualização da pena, que, frequentemente, fica comprometido em razão da realidade carcerária brasileira. Essa circunstância reforça, assim, a necessidade de que a transposição ocorra de forma criteriosa, a fim de que se torne verdadeiramente eficaz.

\section{REFERÊNCIAS}

ALEXY, Robert. Constitucionalismo discursivo. 2. ed. Porto Alegre: Livraria do Advogado, 2008.

ARAGÃO, Alexandre Santos de. A concepção pós-positivista do princípio da legalidade. Revista de Direito Administrativo - RDA, 236. Rio de Janeiro, p. 51-64, Abr./Jun., 2004. 
2013.

Curso de direito administrativo. 2. ed. rev. atual. e ampl.. Rio de Janeiro: Forense,

ARAÚJO, Valter Shuenquener de. Direito administrativo sancionador no Brasil: uma contribuição para a efetividade dos direitos fundamentais. In: ARABI, Abhner Youssif Mota.

MALUF, Fernando; MACHADO NETO, Marcello Lavenère (Coord.). Constituição da República 30 anos depois: uma análise prática da eficiência dos direitos fundamentais. Estudos em homenagem ao ministro Luiz Fux. Belo Horizonte: Fórum, 2019, p. 435-448.

. O Princípio da Proteção da Confiança. Uma Nova Forma de Tutela do Cidadão Diante do Estado. $2^{\text {a }}$ edição. Editora Impetus, 2016.

ÁVILA, Humberto. Teoria dos princípios: da definição à aplicação dos princípios jurídicos. 17. Ed. Ver. e atual. São Paulo: Malheiros, 2016.

BARCELLOS, Ana Paula de. Curso de direito constitucional. Rio de Janeiro: Forense, 2018. BAPTISTA, Patrícia Ferreira. Transformações do direito administrativo. 2. Ed., rev. atual. e ampl. Rio de Janeiro: Lumen Iuris, 2018.

BINENBOJM, Gustavo. A constitucionalização do direito administrativo no brasil: um inventário de avanços e retrocessos. Revista Eletrônica sobre a Reforma do Estado, n. 13, mar./abr./maio 2008. Salvador. Disponível em:

<http://www.ufjf.br/siddharta_legale/files/2014/07/A-Constitucionaliza\%C3\%A7\%C3\%A3odo-direito-administrativo-no-Brasil.pdf> Acesso em: 15 de jan. de 2019.

BINENBOJM, Gustavo. Poder de polícia, ordenação, regulação: transformações políticojurídicas, econômicas e institucionais do direito administrativo ordenador. $2^{\mathrm{a}} \mathrm{ed}$. Belo Horizonte: Fórum, 2017.

BINENBOJM, Gustavo. Uma teoria do direito administrativo: direitos fundamentais, democracia e constitucionalização. $3^{\mathrm{a}}$ ed., rev. e atual., Rio de Janeiro: Renovar, 2014. BITTENCOURT, Cezar Roberto. Tratado de direito penal: parte geral, volume 1. 11. ed. atual. São Paulo: Saraiva, 2007.

BOCKIE, Tiago. A Administração Pública consensual como meio alternativo à imposição de sanção administrativa disciplinar: a concretização do princípio constitucional da eficiência. In: CÂMARA, Alexandre Freitas. PIRES, Adilson Rodrigues. MARÇAL, Thais Boia (Coords.) Estudos de direito administrativo em homenagem ao professor Jessé Torres Pereira Junior. Belo Horizonte: Fórum, 2016.

CARVALHO FILHO, José dos Santos. Manual de direito administrativo. 31 ed. rev. e atual. e ampl. São Paulo: Atlas, 2017.

CYRINO, André. Delegações legislativas, regulamentos e administração pública. Belo Horizonte: Fórum, 2018.

FARIA, Margarida Ermelinda Lima de Morais de. O sistema das sanções e os princípios do Direito Administrativo Sancionador. Dissertação de Mestrado. Universidade de Aveiro, 2007. 
FERREIRA, Daniel. Teoria Geral da infração administrativa a partir da Constituição Federal de 1988. Belo Horizonte: Editora Fórum, 2009.

FRAGOSO, Heleno Cláudio. Lições de direito penal. Parte geral. $16^{\mathrm{a}}$ ed. rev. por Fernando Fragoso. Rio de Janeiro: Forense, 2003.

ESTORNINHO, Maria João. Réquiem pelo contrato administrativo. Coimbra: Almedina, 2003, p. 128.

GILISSEN, John. Introdução Histórica ao Direito. Trad. de A.M. Hespana e L.M. Macaísta Malheiros. Lisboa: Fundação Calouste Gubenkian, 2001.

GRECO, Rogério. Direito Penal: Lições. Rio de Janeiro: Impetus, 2000.

HUNGRIA, Nélson. Comentários ao Código Penal. V. 1, T. 2. Rio de Janeiro: Forense, 1977.

JESUS, Damásio de. Direito penal, volume I: parte geral. 35ª ed. São Paulo: Saraiva, 2014.

JORDÃO, Eduardo. Acabou o romance: reforço do pragmatismo no direito público brasileiro. Revista de Direito Administrativo - RDA, Rio de Janeiro, Edição Especial: Direito Público na Lei de Introdução às Normas de Direito Brasileiro - LINDB (Lei nº 13.655/2018), p. 63-92, nov. 2018.

JUNIOR, Edilson Pereira Nobre. Sanções administrativas e princípios de direito penal.

Revista de Direito Administrativo - RDA. Rio de Janeiro, n. 219, pp. 127-151, jan./mar. 2000.

JUSTEN FILHO, Marçal. Curso de Direito Administrativo. São Paulo: Ed. Revista dos Tribunais, 2014.

MAYER, Otto. Derecho Administrativo Alemán. Tomo I: Buenos Aires: De Palma, 1949.

MELLO, Celso Antônio Bandeira de. Curso de Direito Administrativo. $29^{\text {a }}$ edição. São Paulo: Editora Malheiros, 2012.

MELLO, Rafael Munhoz de. Sanção administrativa e o princípio da culpabilidade. A\&C Revista de Direito Administrativo e Constitucional, Belo Horizonte, ano 5, n. 22, p. 25-57, out./dez. 2005. Disponível em:

<http://www.bidforum.com.br/bid/PDI0006.aspx?pdiCntd=33322> Acesso em: 10 de jan. de 2019.

MENDES, Gilmar Ferreira e BRANCO, Paulo Gustavo Gonet. Curso de Direito Constitucional. 10. ed. rev. e atual. São Paulo: Saraiva, 2015.

MENDONÇA, José Vicente dos Santos de. Direito Administrativo Sancionador e Inovação: limites e possibilidades. Revista de Direito Administrativo e Constitucional. v. 17, n. 69, julho/setembro, p. 169-189, 2017.

MIR PUIG, Santiago. Introducción a las bases del derecho penal: concepto y método. $2^{\circ}$ edición. Editorial B de f. Montevideo, Buenos Aires: 2003 
MIRANDA, Francisco Cavalcanti Pontes de. Comentários à Constituição de 1967. São Paulo: RT. 1971. v. V, p. 1.

MOREIRA NETO, Diogo de Figueiredo; GARCIA, Flávio Amaral. A principiologia no Direito Administrativo Sancionador. Revista Brasileira de Direito Público - RBDP, Belo Horizonte, ano 11, n. 43 out./dez. 2013. Disponível em:

<http://www.bidforum.com.br/bid/PDI0006.aspx? pdiCntd=98862>. Acesso em: 07 de jan. de 2019.

MUÑOZ CONDE, Francisco. ARÁN, Mercedes García. Derecho Penal: Parte general. $8^{\circ}$ edición, revisada y puesta al día. Tirant lo blanch: Valencia, 2010.

NUCCI, Guilherme de Souza. Código Penal Comentado. $17^{\mathrm{a}}$ ed. re., atual. e ampl. Rio de Janeiro: Forense, 2017.

NUCCI, Guilherme de Souza. Individualização da pena. São Paulo: Rev. dos Tribunais, 2005.

OLIVEIRA, Ana Carolina Carlos de. Direito de intervenção e direito administrativo sancionador: o pensamento de Hassemer e o direito penal brasileiro. Dissertação (Mestrado em Direito) - Faculdade de Direito da Universidade de São Paulo, São Paulo. 2012.

PEREIRA, Jane Reis Gonçalves. Interpretação constitucional e direitos fundamentais. 2. Ed. São Paulo: Saraiva Educação, 2018.

PRATES, Marcelo Madureira, Sanção Administrativa Geral: Anatomia e Autonomia, Coimbra: Almedina, 2003.

ROXIN, Claus. Derecho penal, Tomo I, Madrid: Civitas, 1997.

SANTOS, Eduardo Sens dos. Tipicidade, Antijuridicidade e Culpabilidade nas Infrações Administrativas. Fórum Administrativo - Direito Público - FA, Belo Horizonte, ano 4, n. 42, ago. 2004. Disponível em: <http://www.bidforum.com.br/bid/PDI0006.aspx?pdiCntd=5344> Acesso em: 08 de jan. de 2019.

SARLET, Ingo Wolfgang. MARINONI, Guilherme. MITIDIERO, Daniel. Curso de direito constitucional. 6. ed. São Paulo: Saraiva, 2017.

SCHREIBER, Anderson. Manual de direito civil contemporâneo. São Paulo: Saraiva Educação, 2018.

SOUZA, Artur de Brito Gueiros e JAPIASSÚ, Eduardo Adriano. Curso de direito penal: parte geral. $2^{\mathrm{a}}$ ed. rev., atual. e ampl. Rio de Janeiro: Forense, 2015.

TANGERINO, Davi de Paiva Costa. Culpabilidade no Estado Democrático de Direito, pp. 121-128. In: Responsabilidade e pena no Estado Democrático de Direito: Desafios teóricos, políticas públicas e o desenvolvimento da democracia. Orgs. MACHADO, Marta R. de Assis; PUSCHEL, Flavia Portella. São Paulo: FGV Direito SP, 2016. 
VORONOFF, Alice. Direito Administrativo Sancionador no Brasil. Belo Horizonte: Fórum, 2018.

ZAFFARONI, Eugênio Raúl e PIERANGELI, José Henrique. Manual de direito penal brasileiro: parte geral. $5^{\text {a }}$ ed. rev. e atual. São Paulo: Editora Revista dos Tribunais, 2004.

; BATISTA, Nilo; ALAGIA, Alejandro e SLOKAR, Alejandro. Direito Penal Brasileiro: primeiro volume - Teoria Geral do Direito Penal. $2^{\mathrm{a}}$ edição. Rio de Janeiro: Revan, 2003.

Trabalho recebido em 03 de março de 2019

Aceito em 07 de junho de 2020 